\title{
Natural emergencies
}

\author{
Ravshanova Inoyatkhon Erkinovna ${ }^{1}$ \\ ${ }^{1}$ Kokand named after Muqimi \\ State pedagogical institute \\ Methods of teaching biology \\ Senior Lecturer of the Department
${ }^{2}$ Kokand named after Muqimi
State pedagogical institute
Methods of teaching biology
Teacher of the department \\ Shermatova Yoqutkhon Sobirovna ${ }^{2}$
}

\begin{abstract}
Natural disasters are casualties that occur outside of human consciousness and activity. They can occur quickly or gradually. These are events that end with the disappearance. Natural disasters: landslides, floods, strong winds, fires, droughts, landslides, avalanches, rain. Some natural emergencies lead to the development of man-made emergencies. The causes of earthquakes are divided into: - Tectonic earthquakes; - volcanic earthquake;
\end{abstract}

KEY WORDS: disaster, volcanic channel, earthquake.

\section{Introduction}

A volcano is a geological structure that releases lava, hot gas, water vapour, and rock fragments through cracks and canals in the Earth's crust. At the center of the volcano is the main volcanic channel, through which magma and other volcanic rocks rise from the magma basin in the upper mantle.

- Overturning, landslides;

- Man-made (engineering with human activity) earthquakes are recorded annually by seismic instruments (seismographs) of more than 100,000 earthquakes (points of different levels). The catastrophic destruction of about a hundred of them is the destruction of buildings and structures, the formation of cracks in the earth, leading to the death of people.

\section{Main part}

- The surface of the earthquake depth, up to $70 \mathrm{~km}$, on average 70-300 km, the depth can be located in the mantle layer below $300 \mathrm{~km}$. $70 \mathrm{~km}$ of earthquakes occur in the country. The main indicators of earthquakes are: the depth of the epicenter, the amplitude of the earthquake and the intensity of the earthquake. Earthquakes of the twentieth century were observed in the following countries (places): 180 thousand people in China in 1920; 100,000 in Japan in 1923; 110,000 in Ashgabat in 1948; 12,000 in Morocco in 1960; 16,000 in Iran in 1968; 66,000 in Peru in 1970; 66,000 in Thailand in 1990; 18,000 people in Turkey in 1999; In 1988, 25,000 people died in an earthquake in Armenia.

Republic of Armenia (Hayastani Hanrapetutyun) - Transcaucasian southern part of the country. It is bordered by Georgia to the north, Azerbaijan to the east, Iran to the south, and Turkey to the west. There are 37 districts, 27 cities, 31 towns. Since 2000, earthquakes have occurred in Indonesia with a magnitude of 6.9-7.9, causing all the devastation. Earthquake strength is measured in two ways:

1. In points

2. Magnitude

In many countries around the world, the strength of an earthquake is measured in 12 international units. The score indicates the level of vibration of the earth's surface. Action is a philosophical category that describes variability (see Stability and variability), which is an integral part of being. The concept of H. reflects the realization of possibilities, the events that take place, the constant renewal of the universe.

Measured using a seismograph

This measurement was developed at the Russian Academy of Sciences (Medvedev, Shponhoer and Karshin). The seismic acceleration of odd rock particles in the epsenter is estimated by comparing them with the changes that occur there (fracture, rupture, destruction).

The second unit of measurement is the magnitude on the Richter scale. In 1935 it was proposed by the American seismologist I. Richter. Depending on the magnitude of the earthquake, the damage caused by the magnitude of 1-12 varies. In 1966, the Tashkent earthquake had a magnitude of 8 and buildings were severely damaged. The tremors were repeated from time to time overnight. As a result, 78,000 families were left homeless. 2 million square meters of housing, 7,600-seat schools, 690 2,400-seat shops and 84 different businesses were damaged. Damage to buildings is described as follows:

$1^{\text {st }}$ degree loss: This can cause minor injuries.

$2^{\text {nd }}$ degree loss: Minor injuries occur. Small cracks appear in the walls.

$3^{\text {rd }}$ degree loss: There will be severe damage to buildings, large, deep cracks in the walls. 
$4^{\text {th }}$ degree loss: Complete demolition of the inner walls of buildings and structures occurs.

$5^{\text {th }}$ degree loss: There will be complete demolition of buildings and structures.

Classification of buildings and structures by construction and building materials:

A) Group - raw brick, cotton-walled buildings;

B) Group - constructions made of baked bricks;

V) Group - reinforced concrete and wooden structures.

Group A structures - 6 points - earthquake damage of 2 degrees. Group B structures - damage of 1 degree. When a magnitude 7 earthquake occurs, Group A structures suffer a magnitude 3 loss. 8 points - Group A facilities are level 5 and Group B facilities are also level 3-4. Group C facilities suffer 2 levels of damage. 9 points - Group B facilities Level 4. Group B facilities also suffer 4 levels of damage. 10 points - Buildings in group B - level 5 Buildings in group B - level 4. 11 points - Group B buildings completely collapse. Vertical and horizontal movement of rocks is observed. 12 points - in practice there is no vertical structure on the ground. Given this, it is necessary to comply with some requirements in the construction of housing:

- The presence of large areas in the city should allow to evacuate the population in those places, to build tents;

Population - a set of people (humans) living on Earth or in a particular region, continent, country, district, city. Demography is a special science that studies the population. The processes that take place among the population are the result of biological, geographical, and socio-economic factors.

- Presence of fountains in water basins for fire prevention and extinguishing;

- The distance between buildings should not cause harm to anyone in the event of a building collapse;

- Obsolescence of hydraulic structures;

- Design errors of hydraulic structures;

- Improper use of hydraulic structures.

Landslide damage is the movement of rock layers along the slope under the influence of hydrodynamic, hydrostatic seismic forces. At the same time, houses will be destroyed and crops will remain under the ground. Sliding speed is divided into slow, medium and strong. Strong landslides cause great losses, the mass of which reaches several million, sometimes billions of cubic meters. Ahangaron landslide occurred in 1987 with 700 million cubic meters, Sharora in Tajikistan in 1991, Jigaristan landslide in Ahangaron.

Tajikistan (Tajik: Таджикистан), Republic of Tajikistan (Тajik: Жүмхурии Таджикистан) is a country in south eastern Central Asia. The area is 143,100 thousand $\mathrm{km}^{2}$. Population 8,486,300 people (2014). It is bordered by Uzbekistan to the west and northwest, Kyrgyzstan to the north, China to the east, and Afghanistan to the south.

There are 3 stages of landslides:

Phase 1 is the preparation phase of the slide;

Phase 2 single rock displacement;

Stage 3 is the final stage of the slide.

\section{Conclusion}

Predicting landslides: cracks, cracks in the walls of houses; landslide prevention; not to carry out construction works on sloping lands; not to increase the speed of traffic on steep places; protection of rockgrowing plants; Irrigation and plowing should be avoided.

\section{References:}

1. Tukhtaev A. Basics of ecology and nature protection. Tashkent: "Labour". 1994. 34 p.

2. Ilyosova Z.F. "Fundamentals of life safety" Tashkent: "Labour". 2001. 98 p.

3. Nurxo'jaev AK, YunusovM.Yu., Khabibullaev I.X. Emergencies and protection measures - Tashkent: "University". 2001. 67 p.

4. Tadjiev M., Nematov I. and others. Civil protection in emergencies. T. 2003. 260 p.

5. Belov S.V., Devisilov V.A. and others. Safety of life expectancy. Moscow: MGU. 2003. 360 p.

6. Farmonov A.E., Igamberdiev A.R. Life safety. Tashkent: "University". 2006. 96 p.

7. Ramazanova R.A., Sadikova H.A. Training of nurses for emergencies. Study guide. T.: "New Age Generation". 2006. 515 b.

8. Shefer I.F., Shakhmurova G.A. Safety and protection of a person in emergency situations. Study guide for laboratory studies. T.: TSPU im. Nizami. 2007. $126 \mathrm{p}$.

9. Mikhailov L.A., Solomin V.P., Bezpamyatnikh T.A. and others. Safety of life. 2nd edit. M. 2008. 